\title{
Chemistry of Succinimido Esters. IX. ${ }^{* 1}$
}

\section{Chemical Modification of Soybean Lipoxygenase with $N$-Succinimidyl Benzo- ates and the Oxidation of Linoleic Acid in Hexane-Buffer Biphasic System}

\author{
Kazuhiko IshiKawa and Hirofumi Hirata \\ National Chemical Laboratory for Industry (1-1, Higashi, Tukuba-shi, =305)
}

\begin{abstract}
Soybean lipoxygenase I (LG I : pH optimum of 9.0) was readily $N$-arylcarbonylated by $N$-succinimidyl benzoates ( 1 ) and considerably stable up to a high modification ratio. The rate of self-catalyzed destruction of the modified enzyme was less than that of the native one in a borate buffer $(\mathrm{pH} \mathrm{9.0)}$.

The modification caused expression of the enzyme activity for bringing about oxidation of linoleic acid in hexane-buffer $(\mathrm{pH}$ 6.8) biphasic system. The native enzyme showed no activity due to its instability under the experimental conditions. Activity and stability increased with the modification ratio. When bovine serum albumin (BSA) modified by ( 1 ) was added to this system, nonnmodified LG showed the activity for causing oxidation. From the above results, it is concluded that imparting hydrophobicity to LG I itself and/or the reaction system is an important factor for expression of enzyme activity in a biphasic system.
\end{abstract}

\section{Introduction}

$N$-Succinimidyl ester of carboxylic acid is known to react specifically with amino residues in sphingolipid base ${ }^{1,2)}$ and amino acid ester ${ }^{3)}$ because of the activation of the ester carbonyl residue by electron-withdrawing nature of the $N$-succinimidyl residue. In the previous papers ${ }^{4)-6)}$ on the reactivity of $N$-succinimidyl benzoates (1) with amino compounds, we showed that (1) could be used for the $N$ arylcarbonylation reagent of amino compounds in aqueous solution and chemical modification reagent of Lys residue in protein.

Recently, it was also reported that modified (acylated) lipoxygenase (LG) with $N$ acyloxysuccinimides showed enzyme activity for the oxidation of linoleic acid in the hexane-water biphasic system ${ }^{7,8)}$.

In this paper, we selected $(1)$ as a modifier and studied the oxidation of linoleic acid in the hexane-water biphasic system to clarify the detail mechanism for the occurrence of the enzyme activity under these conditions. Furthermore, the kinetic constants of the modified enzyme in aqueous solution was also measured.

\footnotetext{
*1 Chemistry of Succinimido Ester. VII. : J. Jpn. Oil.
} Chem. Soc. (Yukagaku), 36, 840 (1987)

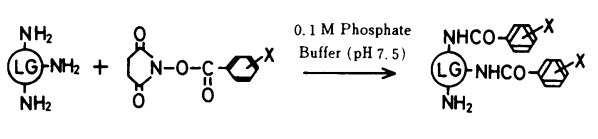

(1)

$$
\begin{array}{lr}
\mathrm{a}: \mathrm{X}=\mathrm{H} & \mathrm{b}: \mathrm{X}=o \cdot \mathrm{CH}_{3} \mathrm{O} \\
\mathrm{c}: \mathrm{X}=m \cdot \mathrm{CH}_{3} \mathrm{O} & \mathrm{d}: \mathrm{X}=p . \\
\mathrm{CH}_{3} \mathrm{O} & \\
&
\end{array}
$$

\section{Experimental}

\subsection{Ma terials}

Soybean lipoxygenase (LG) was purchased from Serva Co., Ltd. and LG I ( $\mathrm{pH}$ optimun of 9.0, LG I was simply signified by LG in the followings) was purified by chromatography on DEAE-TOYOPEARL eluted with a linear sodium phosphate buffer gradient $(0.01 \sim 0.3 \mathrm{M})$ at $\mathrm{pH} 6.8$ according to the procedure of Christopher et al. ${ }^{91}$. Disc electrophoresis on polyacrylamide gel showed the enzyme as one distinct band.

$N$-Succinimidyl benzoates ( 1 ) were prepared from the coupling reaction of benzoic acids (GR grade, from Tokyo Kasei Kogyo Co., Ltd. ) and $N, N$ '-disuccinimidylcarbonate (used for the synthesis of peptides, from Wako Pure Chemicals) by the previously reported method ${ }^{10}$. Sodium 2, 4, 6-trinitrobenzenesulfonate (TNBS : GR grade), sodium sulfite and linoleic acid (> $99 \%$, octadeca-cis-9-cis-12 dienoic acid), were 
purchased from Nakarai Chemicals. Acetonitrile and hexane used were HPLC analytical grade of Wako Pure Chemicals and other solvents were purified by the conventional method ${ }^{11)}$. Other chemicals were of reagent grade of commercial products.

\subsection{Chemical modification}

To a solution of LG dissolved in phosphate buffer $(\mathrm{pH} 7.5,1 \mathrm{mg} / \mathrm{mL}, 10 \mathrm{~mL})$ was added the solution of $(1)$ dissolved in dioxane $\left(5 \times 10^{-4} \sim\right.$ $\left.10^{-2} \mathrm{M}, 1 \mathrm{~mL}\right)$. The mixture was incubated at $25^{\circ} \mathrm{C}$ for $15 \mathrm{~h}$, and these modified enzyme solutions were dialyzed against sufficient phosphate buffer $(\mathrm{pH} 6.8,0.01 \mathrm{M})$ at $4^{\circ} \mathrm{C}$. This solution was used for the subsequent experiments. Chemical modification of BSA by ( 1 ) was also carried out with the above method.

LG concentration was estimated from the absorbance at $280 \mathrm{~nm}$ assuming $E_{1 \mathrm{~cm}}^{1 \%}=14.3^{12}$. Modified LG concentration was measured with the method of Lowry ${ }^{13)}$ on the basis of the above value. Modification ratio were measured by the extinction at $420 \mathrm{~nm}$ of Meisenheimer complex using TNBS and $\mathrm{Na}_{2} \mathrm{SO}_{3}$ with the method reported previously ${ }^{14}$.

\subsection{LG reaction in aqueous solution}

The oxygenation reactions were initiated by addition of aliquots of solutions of LG (2 $30 \mu \mathrm{L}, 1 \mathrm{mg} / \mathrm{mL})$ to $3.0 \mathrm{~mL}$ of $0.05 \mathrm{M}$ borate buffer ( $\mathrm{pH}$ 9.0) containing freshly prepared sodium linoleate $(50 \sim 150 \mu \mathrm{M})$. Assays of LG were performed at $25^{\circ} \mathrm{C}$ in a cuvette exposed to air by continuous monitoring the absorbance at 234 $\mathrm{nm}$ due to the formation of the hydroperoxy diene products on the JASCO UV-430 spectrophotometer. A molar extinction coefficient of 28,000 $\left(\mathrm{M}^{-1} \cdot \mathrm{cm}^{-1}\right)^{15}$ was used to convert absorbance readings to moles of diene products. Under these conditions, this enzyme reaction occurred with a kinetic lag period which might be due to the activation of the enzyme by the products ${ }^{12)}$. In order to remove the kinetic lag period, diene products $(>5 \mu \mathrm{M})$ which was produced by LG were added to the substrate solution before initiating the reaction.

The rate constants for the inactivation $\left(k_{\mathrm{d}}\right)$ of LG during the reaction were measured by the method reported by Smith et $a l^{12}$.

Michaelis constants $\left(K_{\mathrm{m}}\right)$ for LG catalyzed oxidation of sodium linoleate in the buffer solu- tion were determined by the nonlinear leastsquares method using Tailor expansion ${ }^{16}$.

\subsection{LG reaction in biphasic system}

A mixture of buffer solution $(\mathrm{pH} 6.8,0.05 \mathrm{M})$ containing LG solution $(0.5 \mathrm{mg} / \mathrm{mL}, 2 \mathrm{~mL})$ and hexane solution $(25 \mathrm{~mL})$ containing linoleic acid $(2.5 \mathrm{mg} / \mathrm{mL})$ was stirred at over $500 \mathrm{rpm}$ at $30^{\circ} \mathrm{C}$. After the appropriate time, an aliquot of a hexane solution was evaporated in an atmosphere of nitrogen and diluted with $10 \%$ water-methanol containing $0.1 \%$ phosphoric acid, and absorbance at $234 \mathrm{~nm}$ was measured. The residual activity of LG was measured at $\mathrm{pH} 9.0$ as described in $2 \cdot 3$.

\subsection{Analysis of the products}

The reaction products in aqueous and biphasic systems were analyzed by the method reported previously ${ }^{7), 8}$.

\section{Results}

\subsection{Chemical modification of LG}

Amino residues which were located on the surface of the LG could be $N$-arylcarbonylated by (1) in the phosphate buffer $(\mathrm{pH} 7.5,0.1 \mathrm{M})$ at $25^{\circ} \mathrm{C}$.

Fig. -1 indicates the decrease of activity of LG modified by ( $1 \mathrm{a})$ in a borate buffer ( $\mathrm{pH} 9.0$, $0.05 \mathrm{M})$. The enzyme activity did not almost change until the modification ratio of $70 \%$ and decreased gradually over that. The same results were obtained for other reagents $(1 \mathrm{~b}) \sim(1 \mathrm{~d})$. No significant change in circular dichroism spectrum $(200 \sim 250 \mathrm{~nm})$ of LG by the modification was observed. These observations suggested that $L G$ was stable against the modification by (1).

In the previous paper ${ }^{8}$ on the modification with

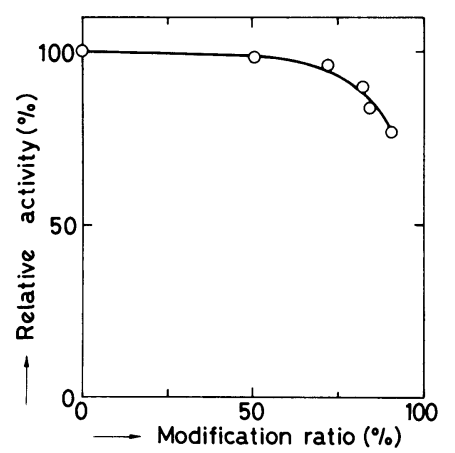

Fig. -1 Chemical modification of LG by (1 a). Plots of relative activity $v s$. the modification ratio. 
$N$-acyloxysuccinimide, we reported that the decrease of $L G$ activity modified with $C N=2,4,6$ ( $\mathrm{CN}$ : carbon number of acyl residue) was small but it became large for $\mathrm{CN}=8$. The phenomenon of the decrease of the LG activity by modification with ( 1 ) seems to correspond to that with $\mathrm{CN}=$ 6.

\subsection{Activity of the modified LG in the aqueous solution}

\section{$3 \cdot 2 \cdot 1$ Lag period $(\tau)$}

A kinetic lag period $(\tau)$ was reported for the $L G$ reaction in the absence of the hydroperoxide products $^{12}$. The lag period for the modified LG was measured at $\mathrm{pH} 9.0$ and $25^{\circ} \mathrm{C}$. The results are summarized inTable-1, which shows the decrease in lag period $(\tau)$, that is, LG was activated by the modification with $(1)$.

$3 \cdot 2 \cdot 2 \quad V_{\max }$ and $K_{\mathrm{m}}$

The representative Michaelis constant $\left(K_{\mathrm{m}}\right)$ and the maximum velocity $\left(V_{\max }\right)$ were determined for the $L G$ reaction in the presence of dienes $(2 \cdot 3)$ at $25^{\circ} \mathrm{C}$. The representative Michaelis-Menten plots were shown in Fig. -2 . The values of $V_{\max }$ and $K_{\mathrm{m}}$ were also listed in Table-1. $V_{\max }$ decreased slightly with increasing the modifiation ratio and was independent of the substituent in (1). But $K_{\mathrm{m}}$ values of sodium linoleate for modified LG were larger than that for

Table-1 The effects of the modification on lag period, $V_{\max }, K_{\mathrm{m}}$ and inactivation constant $\left(k_{\mathrm{d}}\right)$ for the oxidation of sodium linoleate in the borate buffer ${ }^{\mathrm{a}}$.

\begin{tabular}{|c|c|c|c|c|c|}
\hline (1) & $\begin{array}{l}\text { Modification } \\
\text { ratio (\%) }\end{array}$ & $\begin{array}{c}\text { Lag period } \\
(\tau)(\mathrm{s})\end{array}$ & $\begin{array}{r}V_{\max } \\
(\mu \mathrm{M} / \mathrm{s})\end{array}$ & $\left(\begin{array}{l}K_{\mathrm{m}} \\
(\mu \mathrm{M})\end{array}\right.$ & $\begin{array}{l}10^{2} k_{\mathrm{d}} \\
\left(\min ^{-1}\right)\end{array}$ \\
\hline \multirow{6}{*}{ (1a) } & 0 & 18. 1 & 0.78 & 15.8 & 2. 18 \\
\hline & 50 & 10. & 0.76 & 30.7 & 1.80 \\
\hline & 72 & & 0.74 & 31.0 & 1.52 \\
\hline & 82 & 9.3 & 0.70 & 30.9 & 1.45 \\
\hline & 84 & 11 & 0.66 & 32.4 & 1.61 \\
\hline & 91 & 10.8 & 0.60 & 34.2 & 1.74 \\
\hline \multirow{2}{*}{ (1b) } & 61 & 9.2 & 0.75 & 30.1 & 1.68 \\
\hline & 80 & & 0.68 & 32.1 & 1.55 \\
\hline \multirow{2}{*}{ (1c) } & 60 & 9.8 & 0.71 & 32.3 & 1.70 \\
\hline & 85 & 11.2 & 0.62 & 33.0 & 1.60 \\
\hline \multirow{2}{*}{ (1d) } & 58 & 9. & 0.74 & 31.5 & 1.81 \\
\hline & 77 & 11.3 & 0.69 & 34.8 & 1.53 \\
\hline
\end{tabular}

a) $\mathrm{pH} 9.0(0.05 \mathrm{M}), T=25^{\circ} \mathrm{C}$, enzyme concentration : $1 \mu \mathrm{g} / \mathrm{mL}$.

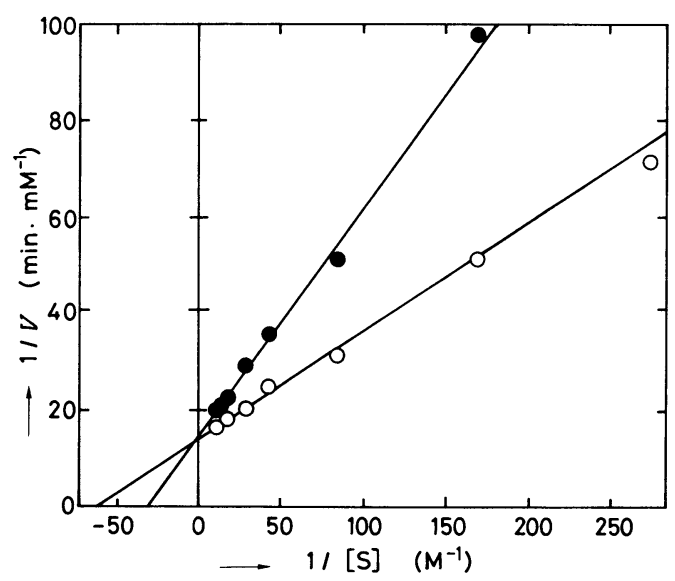

Fig. -2 Plots of $1 / v$ vs. $1 / s$ for the oxidation of sodium linoleate catalyzed by native $\mathrm{LG}(\mathrm{O})$ and modified LG by (1 a) (O) (modification ratio : $91 \%)$ in borate buffer $(\mathrm{pH} \mathrm{9.0,} 0.05$ $\mathrm{M})$ at, $25^{\circ} \mathrm{C}$ and enzyme concentration of 1 $\mu \mathrm{g} / \mathrm{mL}$.

native one. Previously, we reported that $K_{\mathrm{m}}$ values for $\mathrm{L} G$ modified by $\mathrm{CN}=2,4$ and $\mathrm{CN}=6,8$ were about 30 and $50 \mu \mathrm{M}$, respectively ${ }^{8)}$. The values of $K_{\mathrm{m}}$ for LG modified by ( 1 ) seems to correspond to those for $\mathrm{CN}=2,4$.

\section{$3 \cdot 2 \cdot 3$ Self-catalyzed destruction}

The active site of LG I was destroyed during the enzyme reaction catalyzed the oxidation of sodium linoleate in the borate buffer. The kinetic model for self-catalyzed destruction of LG was reported by Smith $e t a l^{21}$ as follows :

$$
V_{t}=\mathrm{d}[\mathrm{P}] / \mathrm{d} t=\frac{k_{\mathrm{d}}[\mathrm{P}]}{\frac{K_{\mathrm{m}}}{[\mathrm{S}]}+1}
$$

where $\mathrm{E}, \mathrm{E}^{*}, \mathrm{P}$ and $\mathrm{S}$ are active and inactivated LG, product and substrate, respectively. Since the reaction was carried out under the conditions of $[\mathrm{S}]>K_{\mathrm{m}}$, the values of the first order rate constants $\left(k_{\mathrm{d}}\right)$ were determined from the slopes of the plots of instantaneous velocity versus substrate concentration at time $t$. The $k_{\mathrm{d}}$ values of modified LG were smaller than that of native LG as shown in Table-1. This result means that the stability of LG during the reaction increases by the modification. 


\subsection{LG reaction in the hexane- buffer biphasic system}

$3 \cdot 3 \cdot 1$ Appearance of the enzyme activity in the biphasic system by the modification

Native LG (Non-modified LG) was unstable to hexane, and inactivated rapidly in the biphasic system, i.e., only a small amounts of conjugated dienes were produced for the oxidation of linoleic acid. On the other hand, modified LG by (1) was stable for a certain period and accumulation of the diene products in hexane was observed (Figs. -3 and 4 ). The activity of modified LG in the biphasic system increased with increasing modification ratio. Similar results were obtained with respect to ( $1 \mathrm{~b})$ and $(1 \mathrm{~d})$. These show that activity of the modified LG is almost independent

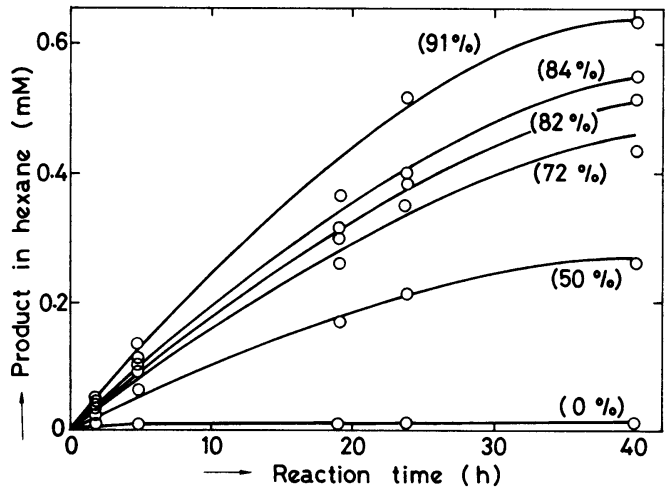

Fig. -3 Time course for the oxidation of linoleic acid catalyzed by LG modified with ( $1 \mathrm{a}$ ) in the biphasic system at $30^{\circ} \mathrm{C}$.

Modification ratios were designated in parentheses.

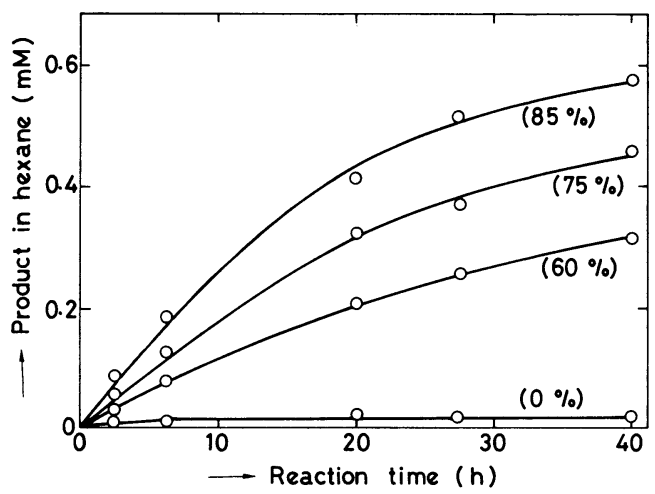

Fig. -4 Time course for the oxidation of linoleic catalyzed by modified with (1 c) in the biphasic system.

Modification ratios were designated in parentheses. of substituent in the modifier.

$3 \cdot 3 \cdot 2$ Stability of LG in the biphasic system

Stability of LG in the biphasic system in the absence of the substrate at $30^{\circ} \mathrm{C}$ was examined. The results are shown in Fig. -5 . The nonmodified LG was inactivated completely for about $50 \mathrm{~min}$. On the other hand, the enzyme was stabilized by the modification with ( 1 a) and the half life periods of the modified LG increased with increasing the modification ratio. In the presence of linoleic acid, the half life periods of modified LG were somewhat $(20 \sim 30 \%)$ longer than that in the absence of linoleic acid. Similar results were obtained with respect to $(1 \mathrm{~b}) \sim(1$ d).

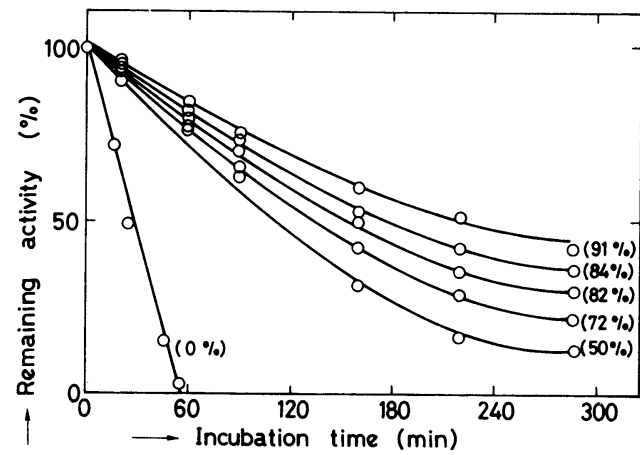

Fig. -5 Stability of LG in the hexane-buffer biphasic system in the absence of linoleic acid at $30^{\circ} \mathrm{C}$. Modified LG in buffer $=0.5 \mathrm{mg} / \mathrm{mL}$. Modification ratios were designated in parentheses.

\subsubsection{Effect of the additives}

The effect of the additives on the oxidation of linoleic acid catalyzed by native LG was examined. BSA, glycerol, casein and $\mathrm{NaCl}$ which are thought to be stabilizers of the enzymes and methanol to be the surface activator between hexane and water showed no effect on the reactivities. On the other hand, the addition of the modified BSA by ( 1 a) (modification ratio= $80 \%$ ) was found to activate native LG in the biphasic system, and the conjugated dienes were accumulated in the hexane layer as shown in Fig. -6 . The activity increased with increasing of the concentration of modified BSA (Fig. -6).

$3 \cdot 3 \cdot 4$ Analyses of the products

In the biphasic system, the oxidized products were analyzed by HPLC. Three main products (13-hydroperoxy-cis-9-trans-11-octadecadienoic 


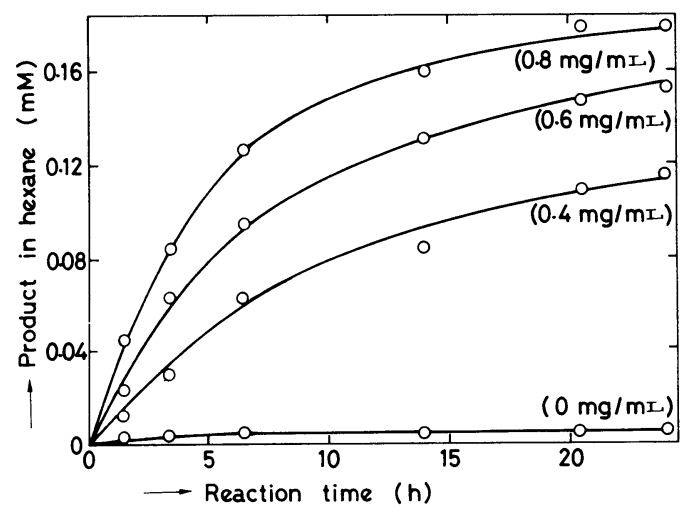

Fig. -6 Effect of BSA modified by (1 a) in the biphasic system. Time course of the conversion of linoleic acid catalyzed by native LG in the biphasic system at $30^{\circ} \mathrm{C}$. Concentration of modified BSA was designated in parentheses.

acid, 13-hydroperoxy-trans-9-trans-11-octadecadienoic acid and 9-hydroperoxy-cis-10-trans11-octadecadienoic acid) were detected. And these products and their ratios of these were the same as those for the biphasic reaction catalyzed by modified LG with $N$-acyloxysuccinimides.

\section{Discussion}

\subsection{Improvement of LG functions in the aqueous solution by the modification}

LG was stable against the modification with (1) and the activity was remained until the modification ratio of $70 \%$ (Fig. -1 ). The lag period $^{12)}$ of this enzyme reaction in the buffer solution was decreased by the modification $(3 \cdot 2)$. These results suggest that the modified LG was more activated by the product or less inhibited by the substrate (sodium linoleate) in the process of the activation of the enzyme. Furthermore, the first order rate constant $\left(k_{\mathrm{d}}\right)$ for the self-catalyzed destruction of LG decreased by the modification (Table-1), that is, the stability of LG during the reaction increased by the modification. $K_{\mathrm{m}}$ value of sodium linoleate was increased by this modification, that is, the affinity of the active center in LG for sodium linoleate decreased. The similar improvement of enzyme functions was also reported for the chemial modification by $N$-acyloxysuccinimides ${ }^{8}$. From the above facts, it is speculated that the amino residues modified by ( 1 ) are not located at the active center of $L G$, but somewhat related to the inactivation step $\left(\left[\mathrm{E} \cdot \mathrm{O}_{2} \cdot \mathrm{P} \cdot \mathrm{S}\right] \longrightarrow \mathrm{E}^{*}\right)$ and the activation step by the product.

\subsection{Appearance of LG activity in the hexane-buffer biphasic system}

Usually, LG activity is observed in the buffer solution containing sodium linoleate as substrate or containing linoleic acid dispersed with surfaceactive agent (Tween 20 etc. $)^{9}$. But we encountered difficulties of the reaction at the high substrate concentration and extraction of the products. Organic-aqueous biphasic system was able to eliminate them. In this system, the reaction seems to be carried out at the interface between hexane and water. Native LG was unstable in the presence of hexane and no reactivity was observed in the system. However, the modified LG endowed with hydrophobicity by (1) was somewhat stable and showed the activity. The stabilities and reactvities increased with increasing the hydrophobicity by the modification, but they were independent of the substituent in ( 1$)$, i.e., these phenomena were due to the aryl group in (1) not to the substituent groups of ( 1 ).

Addition of BSA modified by ( 1 ) also caused the enzyme activity of native $L G$ in the biphasic system, although casein, $\mathrm{BSA}$, glycerol, $\mathrm{NaCl}$ and methanol showed no positive effects. The activity increased with increasing the concentration of modified BSA. These results indicate that the $N$-arylcarbonylated parts of the proteins by (1) served as stabilizers and activators of this enzymes in the biphasic system. This demonstrates that in the case that enzymes are inactivated by this modification, additions of other proteins modified by (1) may stabilize and activate the enzymes in this system.

The activity of the modified LG by (1) is comparable with that by $N$-acyloxysuinimides $(\mathrm{CN}=6$ and 8$)$. However, the activity in the presence of BSA modified with (1) was smaller than that with $N$-acyloxysuccinimides $(\mathrm{CN}=6$ and 8 ). These conclude that additional hydrophobicity to LG itself and/or the biphasic system is an important factor for causing LG activity in it.

(Received Nov. 4, 1987)

\section{References}

1) H. Hirata, Yukagaku, 33, 12 (1984);29, 2 
(1980).

2) H. Hirata, K. Higuchi, S. Nakasato, and G. J. Schroepfer, Jr., J. Jpn. Oil. Chem. Soc. (YUKAGAKU), 35, 18 (1986).

3) H. Ogura and T. Takeda, Nippon Kagakukaishi, 1982, 836.

4) K. Higuchi, K. Ishikawa, T. Yamashina, and H. Hirata, J. Jpn. Oil. Chem. Soc. (YUKAGAKU), 36, 176 (1987).

5) H. Hirata and T. Yamashina, J. Jpn. Oil. Chem. Soc. (YUKAGAKU), 36, 555 (1987).

6) H. Hirata and T. Yamasina, "Chemistry of Succinimido Esters. Kinetic Studies on the $N$-Arylcarbonylation of Aliphatic Primary Amines by $N$-Succinimidyl Benzoate in Aqueous Solution", Submitted to J. Jpn. Oil. Chem. Soc. ( YUKAGAKU).

7) H. Hirata, K. Ishikawa, and K. Higuchi, $J$. YUKAGAKU, 36, 343 (1987).

8) H. Hirata, K. Higuchi, and K. Ishikawa, "Oxidation of Linoleic Acid Catalyzed by Soybean Lipoxygenase I (Optimum pH 9.0) in Hexane-Water Biphasic System-Appearance of the Enzyme Activity by Chemical Modification and Addition of Modified Bovine Serum Albumin", Submitted to J. Jpn. Oil Chem. Soc. ( YUKAGAKU)

9) J. Christopher, E. Pistorius, and B. Axelrod, Biochim. Biophys. Acta., 198, 12 (1970).

10) K. Higuchi, T. Yamashina, K. Ishikawa, and H. Hirata, J. Jpn. Oil. Chem. Soc. (YUKAGAKU), 36, 16 (1987).

11) J.A. Riddick and W.B. Bunger, "Organic Solvent”, Wiley-Interscience, New York, London, Sydney, Toronto (1970), p. 552.

12) W. L. Smith and W.E. M. Lands, J. Biol. Chem., 247, 1038 (1972).

13) K. Sugawara and M. Soejima, "Determination of Proteins”, Gakkai Shuppan Center (1977) p. 93 .
14) T. Yamashina and H. Hirate, J. Jpn. Oil Chem. Soc. (YUKAGAKU), 36, (1987).

15) A. L. Tappel, P.D. Boyer, and W. O. Lundberg, J. Biol. Chem., 199, 267 (1952)

16) M. Sakoda and K. Hiromi, J. Biochem. , 80, 547 (1976)

スクシンイミドエステルの化学 (第 9 報)

$N$-スクシンイミジルベンゾエートによる大豆

リポキシゲナーゼの化学修飾及びへキサンー

緩衝液二相系でのリノール酸の酸化反応

石川一彦・平田博文

化学技術研究所（テ305 つくば市東 1-1）

二相系 (水-有機溶媒) において酵素反応を行うこと を目的とした。モデル酵素として，ダイズより得られた リポキシゲナーゼ (LG) を用い， $N$-スクシンイミジル ベンゾエート（1）でアミノ基を修飾し二相系（水-へ キサン) での酵素反応を試みた。

基質（リノール酸）を溶かしたへキサン溶液に，酵素 を溶かした水溶液を加えた二相系においては，未修飾の LG は, 不安定でへキサン中のリノール酸はほとんど酸 化されなかった。しかし，（1）で修飾したLGはある 程度へキサンに対し安定であり，またへキサン中のリ ノール酸の酸化が観察された。また安定性及び反応性は, 修飾率が高い程大きく，すなわち酵素の疎水性を上げる 程安定性及び反応性は, 増大することがわかった。また, このような二相系での反応性は（1）で修飾した BSA を加えることによっても見られるということから，(1) により修飾されたタンパク質が，この系での安定性及び 反応性に寄与するものと考えられた。

以上の結果から（1）が酵素のへキサンに対する安定 性を高める修飾試薬として使用できるものと推論でき る。 